\title{
Review Article \\ Review of Plant Species Diversity in Managed Forests in Japan
}

\author{
Takuo Nagaike \\ Forest Research Division, Yamanashi Forest Research Institute, Fujikawa, Yamanashi 400-0502, Japan \\ Correspondence should be addressed to Takuo Nagaike, nagaike-zty@pref.yamanashi.lg.jp
}

Received 12 March 2012; Accepted 3 May 2012

Academic Editors: T. Heinken, L. Pinkard, and P. Smethurst

Copyright (C 2012 Takuo Nagaike. This is an open access article distributed under the Creative Commons Attribution License, which permits unrestricted use, distribution, and reproduction in any medium, provided the original work is properly cited.

\begin{abstract}
The effects of conifer plantation management and forest fragmentation on plant species diversity in Japan were reviewed. While most studies have demonstrated that the practice of thinning in coniferous plantations can enhance species diversity of naturally regenerated trees, such as broad-leaved trees, some have shown that thinning reduces plant species diversity through the direct physical disturbance to forests. In addition, plant species diversity in plantations has also been shown to be dependent on the distance from seed sources. Extensive forest fragmentation due to land use changes has occurred, particularly in forests near urban and suburban areas. Although the number of species per unit area in abandoned coppice forests is not clearly related to the extent of forest fragmentation, most species attributes (such as rare species) are negatively influenced by forest fragmentation. Some of the forests owned by shrines and temples in urban areas are similar to island forests and are relatively well protected from human disturbance. To more clearly understand and evaluate changes in biodiversity through forest management, elucidating the interactions between management and plant species diversity, species composition, and the ecological traits of various species is therefore necessary.
\end{abstract}

\section{Introduction}

Forest management typically has a marked affect on plant species diversity, which is an important ecological indicator (e.g., [1]). Understanding the effects of forest management practices on plant species diversity is important for achieving ecologically sustainable forest management [2]. Most of the forests that cover Japan's surface are managed; these include plantations, coppices, and selection or selectively cut forests [3]. The plant species diversity of these managed forests is thus important for maintaining, conserving, and restoring biodiversity in Japan. Globally, forest management policy has changed in response to changes in public awareness of the multiple functions of forests [4]. In Japan, studies of plant species diversity in the managed forests of the country have increased markedly since $2000[5,6]$.

Species diversity is an important index in community ecology (e.g., [7]). Although species richness and diversity are useful indicators of the effects of forest management practices, species diversity per se is also important in biodiversity. For example, forest stands with relatively higher species richness or diversity are not always much better for biodiversity, as undesirable species (e.g., invasive or exotic species), which frequently comprise a high proportion of early successional species $[8,9]$, can contribute toward a marked increase in diversity [10-12]. A comprehensive understanding of plant species diversity, species composition, and the ecological traits of species (i.e., plant functional types [13]) is thus considered necessary in order to understand and evaluate the quality of biodiversity $([3,6]$, but see [14]).

This paper reviewed studies on plant species diversity and species composition within the context of forest management (i.e., plantations and forest fragmentation) that have been published, primarily in Japan, over the past 20 years. Since some of these studies have only been published in Japanese (with English summaries), much of the information they contain cannot be accessed by the international audience. The primary aim of this study was therefore to introduce these papers to the international audience.

\section{Studies on Plant Species Diversity and Species Richness in Plantations}

Plantations account for approximately $40 \%$ of Japanese forests (66\% of land area). The most extensively planted 
TABLE 1: Effects of management regime on plant species richness and diversity in plantations in Japan.

\begin{tabular}{|c|c|c|c|}
\hline \multirow{2}{*}{ Management regime } & \multicolumn{3}{|c|}{ Change in plant species richness or diversity } \\
\hline & Increasing & No change & Decreasing \\
\hline \multirow{2}{*}{ Line cutting } & Sakuta et al. [25] & & Ito et al. [26] \\
\hline & Yamagawa et al. [27] & & \\
\hline \multirow{3}{*}{ Thinning } & Hanada et al. [30] & & \\
\hline & Ishii et al. [31] & & Nagai and Yoshida [33] \\
\hline & Hirata et al. [32] & & \\
\hline Rotation frequency & & & Hino and Hiura [36] \\
\hline \multirow[t]{2}{*}{ Age } & Ito et al. [43] & Nagaike et al. [50] & \\
\hline & Nagaike et al. [48] & & \\
\hline \multirow{2}{*}{ Distance from seed sources } & & $\begin{array}{l}\text { Gonzales and Nakashizuka [54] } \\
\text { (seedling) }\end{array}$ & $\begin{array}{l}\text { Takahashi and Kamitani [51] } \\
\text { Gonzales and Nakashizuka [54] } \\
\text { (saplings) }\end{array}$ \\
\hline & & $\begin{array}{l}\text { Utsugi et al. [55] (seedlings and } \\
\text { saplings in unthinned, seed fall } \\
\text { and seed bank in thinned) }\end{array}$ & $\begin{array}{l}\text { Utsugi et al. [55] (seedlings and } \\
\text { saplings in thinned) }\end{array}$ \\
\hline
\end{tabular}

species in Japan are the indigenous evergreen conifers Cryptomeria japonica (Japanese ceder, 4.5 million ha, 43\% of area under plantation) and Chamaecyparis obtusa (Hinoki cypress, 2.6 million ha, $26 \%$ of area under plantation). Since the function of plantations has changed from being single purpose (i.e., timber production) to multipurpose (e.g., habitats for wild animals and plants), studies of plant species diversity [15, 16] as well as ecosystem services and goods [17] provided by plantations have increased markedly (Table 1 ). In a meta-analysis of plant species richness in plantations compared to other land cover types (e.g., primary and secondary forest), Bremer and Farley [15] showed that plantations were more likely to contribute to biodiversity when established in degraded lands than when they replaced natural forest, grassland, and shrubland ecosystems. The reduction of plant species diversity in exotic plantations [12] and the invasion of exotic species into natural forests $[18,19]$ are issues that need to be considered in plantation management.

The trees in plantations should be harvested when they attain a size that is suitable for timber. To maximize the economic efficiency of timber harvesting in plantations, the final cut is usually a clearcut [20]. Among final cutting practices, clearcutting has the biggest effect on microclimate (i.e., soil and air temperature, humidity, and light intensity) and consequently plant species diversity [21]. For example, the diversity of forest floor plants in a subtropical forest in southern Japan did not recover well after the forest was clearcut $[22,23]$. Similarly, the species composition of most plantations and coppice forests in the cool-temperate zone in central Japan that were clearcut at least once, did not revert to primary forest conditions after management was abandoned [24]. As a consequence, alternative methods of clearcutting, line cutting, or strip cutting have been introduced in Japan [25]. However, in C. japonica and C. obtusa plantations in southern Japan, species diversity (Shannon's $\mathrm{H}^{\prime}$ ) in the cut strips was similar to that in the clearcut plantation [26]. To find a way of combining effective timber production with effective management of species diversity, Yamagawa et al. [27] clarified the effects of small-scale clearcutting and suggested that managing different-aged stands using an optimal spatiotemporal arrangement of patches was well suited to maintaining the various understory types, and that such an approach could be used to maximize species diversity through effective patch management.

Tending plantations (e.g., weeding and thinning) is necessary for producing high-quality timber. Appropriate tending, particularly thinning, has been lacking in Japanese plantations because of the lack of economic incentives for forest owners to do so [24]. Since a lack of thinning creates a very dark understory with sparse vegetation, the risk of soil erosion is enhanced [4, 28]. As a result, studies on the effects of thinning on restoring or rehabilitating plant species diversity are increasing. These studies have shown that thinning enhanced the species richness of broadleaved trees in plantations of Abies sachalinensis [29] and Larix kaempferi [30] in northern Japan, and in C. japonica plantations in western [31] and central [32] Japan. However, Nagai and Yoshida [33] showed that thinning of Picea glehnii plantations in northern Japan reduced plant species diversity because of the direct effect of physical disturbance associated with the activity. Line thinning in C. japonica plantations in central Japan contributed little toward the regeneration of hardwood species [32], and thinning intensity increased understory species diversity in Larix leptolepis plantations four years after thinning in central South Korea [34].

To avoid converting natural forests into plantations, the practice of planting a second (or more) rotation crop in plantations is increasing [35]. Since this practice will increase the area of second or multiple-rotation plantations, it is important to understand whether such practices could potentially decrease plant species diversity or future 
plantation productivity, either directly or indirectly. In a study of species diversity and above-ground productivity of understory plants in plantations, Hino and Hiura [36] showed that the Simpson index decreased as the rotation frequency of plantations increased, with the effects of disturbance on species diversity persisting for 20-80 years in a cool-temperate forest in northern Japan. In a loblolly pine (Pinus taeda) plantation in the USA, Jeffries et al. [9] showed overall similarities in the herbaceous layer from year 22 of the second rotation to year 18 of the third rotation, however, these authors were unable to clarify whether species diversity increases, decreases, or remains constant over multiple rotations.

Stand age is a key attribute of plantations because it directly affects the quantity and log size of timber produced, as well as the cutting rotation employed in a landscape. In Japan, long-rotation management is becoming increasingly widespread as it results in the production of larger and more valuable timber and is a way of hedging against fluctuations in the price of timber [37,38]. Long-rotation plantations have been observed to maintain and increase species diversity and develop stand structure better than standard-rotation plantations $[39,40]$. An aged C. japonica plantation was observed to develop a multilayered structure, with planted trees constituting the upper layer and broadleaved trees forming the lower layers [41]. Plant community composition and diversity is significantly related to vertical stand structure, and the development of stand structure has been shown to contribute toward increasing the diversity of plant species in mature and old-growth stands [42]. Stand age has also been shown to be positively correlated to plant species diversity in C. japonica plantations in southern Japan [43] and Picea plantations in Canada [44]. Ramovs and Roberts [45] identified a gradient in cover of foresthabitat species which ranged from being lowest in oldfield plantations, intermediate in cut-over plantations and young, naturally regenerated stands, and highest in mature, naturally regenerated stands. Nagaike [46] showed that the species diversity of snags (standing dead trees), which are an important structural attribute of forest ecosystem diversity $[1,47]$, was positively correlated to stand age in L. kaempferi plantations, supporting the positive correlation between tree species diversity and species richness with stand age [48]. Conversely, in the herb layer of the study plots examined by Nagaike et al. [48], plant species diversity was not correlated with stand age, but the attributes of some species (e.g., weed species) were negatively correlated with stand age and the occurrence frequency of species. Conversely, bird-dispersed seeds were positively correlated with stand age $[49,50]$.

Within the context of ecological restoration, the spatial configuration of stands, particularly the range of seed dispersal by species used in restoration, is considered to be particularly important. Consequently, the relationship between the extent of colonization by plant species in plantations and the distance from seed sources has also been extensively studied in Japan [51] and elsewhere (e.g., $[52,53])$. Gonzales and Nakashizuka [54] demonstrated that although there were no marked or general trends in the frequency and species diversity (Shannon's index) of saplings of naturally regenerated broad-leaved species in relation to distance from old-growth forest in C. japonica plantations in central Japan, the frequency and species richness of seedlings decreased as distance from the old growth forest increased. Utsugi et al. [55] clarified the interactive effects of distance from hardwood forests and thinning on species diversity and abundance of hardwoods in C. japonica plantations in northern Japan and showed that the interactive effects did not decrease the diversity of seedlings and saplings, probably due to distance-independent improvements in environmental conditions resulting from thinning. However, most of these studies were only conducted at the stand level; these effects need to be examined at the landscape level to more accurately reflect the practical management conditions of forested landscapes. Soil seed banks can also contribute to the recovery of vegetation after clearcutting or thinning plantations. For example, high red: far-red light ratios and/or the large temperature fluctuations associated with thinning in $C$. japonica plantations markedly increased seed germination in the understory [56]. However, since the number of late-successional species in the soil seed bank of C. obtusa plantations is low in southwestern Japan, their contribution to the recovery of natural vegetation was also low [57].

\section{Effects of forest Fragmentation on Plant Species Diversity}

The effects of forest fragmentation on plant species diversity and richness are a major research topic in conservation biology and forest management (e.g., [58-60]). In Japan, forest fragmentation, resulting from land use change, has been severe, particularly in areas adjacent to urban and suburban areas. In abandoned coppice forests in central Japan, several studies have shown that the number of species per unit area is not clearly related to the extent of forest fragmentation [61-63]. Although forest fragmentation does not decrease overall species richness, some species (e.g., rare species) have been shown to be particularly sensitive to habitat fragmentation $[61,62]$. For example, the number of species with distributions that were biased toward primeval and natural forests was positively correlated with the patch area of these primeval and natural forests [63]. Ishida et al. [64] showed that, compared to secondary forests, the number of species with distributions that tended toward primeval and natural forests was strongly and positively correlated with forest patch area for these two forest types, implying that forest fragmentation decreases species richness in lucidophyllous forests in western Japan. In a subtropical forest in southern Japan, recovery from clear-cutting was greater in stands surrounded by mature forest than in isolated stands or stands surrounded by immature forest [65].

Some of the forests, owned by shrines and temples in urban areas, have survived as forest islands and are relatively well protected from human disturbance. In a study to clarify the relationship between the lucidophyllous plant diversity and area of these fragmented forests, a strong 
positive correlation was found between the number of species and species that were generally more common in smaller forests [66]. Tamura and Shimano [67] concluded that shrine forests, consisting of cool-temperate species, play an important role as habitats for a variety of native plants (e.g., forest-interior species) in city environments in central Japan. Using umbrella species selected by a focal species approach, Murakami et al. [68] presented planning guidelines for conserving tree species, by selecting the umbrella species, using "focal species approach," in fragmented shrine forests. In this way, such urban forests could contribute to maintaining plant species diversity in highly altered forested landscapes.

Traditionally, coppice forests in Japan were continuously managed for charcoal and firewood production [69]. However, the management of these coppice forests ceased after the advent of fossil fuels such as gas and oil, resulting in these areas becoming increasingly fragmented by conversion to other land use. Matsumura et al. [70] reported that, while the cover of evergreen species (including summer-green species) and species in the herb layer of abandoned coppice forests in western Japan increased after coppice management ceased, both were negatively correlated with overall species abundance in all forest layers.

Dwarf bamboo in the understory markedly affects plant species diversity and tree regeneration (e.g., [71]) as well as forest fragmentation and management. Tomimatsu et al. [72] showed that Sasa chartacea was more abundant in smaller forest fragments and also that the species richness of forest herbs was strongly and negatively related to $S$. chartacea density. Indeed, variations in species richness could, more clearly, be attributed to $S$. chartacea density than to the distance from the nearest forest edge. Forest floor plant diversity was low in areas where Pleioblastus chino, another species of dwarf bamboo, was well established [61]. Since species richness of summer-green perennials was low where coppicing management practices had been interrupted for extended periods [73], traditional continuous management practices are considered to have maintained species richness. However, since the economic incentives for such management methods have been lost, ensuring that they will continue to be applied will be difficult. As an alternative, numerous urban residents have been encouraged to volunteer their services to manage areas in order to maintain plant diversity [74].

\section{Future Research Directions}

Since plant species diversity is known to be markedly affected by spatial scale, sampling procedures should consider the appropriate scale at which to examine plant species diversity within the context of the specific objectives of the study [11]. Moreover, while an increase in biological diversity has been observed in mixed-species production stands, no such increase exists in coniferous monocultures [75]. To accurately assess the multifunctional roles of forests, the important relationship between productivity and species diversity should therefore be examined further. Consequently, this relationship is currently being carefully elucidated in experimental mixed plantations (e.g., [76, 77]). Jobidon et al. [78] showed that the variation in species diversity along the gradient of hardwood abundance in a Picea mariana plantation in Canada had a "hump" shape, which is considered characteristic of the classic disturbancediversity hypothesis. However, the intensity of previous vegetation control measures was weakly predictive of plant species diversity. Forest managers should therefore consider the long-term effects of management history in order to maintain the plant diversity of the forest understory $[36,79]$. Also, plant species diversity and composition would play an important role for ecological function and services. Such kind of studies in managed forest is strongly necessary [17, 80].

\section{Acknowledgments}

This study was funded in part by a Grant-in-Aid for Scientific Research from the Japan Society for the Promotion of Science (22580176) and the Development of Transformation from Coniferous Plantation to Broad-Leaved Forests project of the Agriculture, Forestry, and Fisheries Research Council, Japan.

\section{References}

[1] D. B. Lindenmayer, J. F. Franklin, and J. Fischer, "General management principles and a checklist of strategies to guide forest biodiversity conservation," Biological Conservation, vol. 131, no. 3, pp. 433-445, 2006.

[2] M. K. Dobbertin and M. P. Nobis, "Exploring research issues in selected forest journals 1979-2008," Annals of Forest Science, vol. 67 , no. 8,7 pages, 2010.

[3] T. Nagaike, T. Kamitani, and T. Nakashizuka, "Effects of different forest management systems on plant species diversity in a Fagus crenata forested landscape of central Japan," Canadian Journal of Forest Research, vol. 35, no. 12, pp. 28322840, 2005.

[4] B. H. N. Razafindrabe, H. Bin, S. Inoue, T. Ezaki, and R. Sau, "The role of forest stand density in controlling soil erosion: implications to sediment-related disasters in Japan," Environmental Monitoring and Assessment, vol. 160, no. 1-4, pp. 337-354, 2010.

[5] T. Nagaike, "A review of ecological studies on plant species diversity in plantation ecosystems," Journal of the Japanese Forestry Society, vol. 82, no. 4, pp. 407-416, 2000 (Japanese).

[6] T. Nagaike, "A review of ecological studies on the effects of forest management on plant species diversity," Japanese Journal of Ecology, vol. 52, pp. 35-54, 2002 (Japanese).

[7] J. A. Myers and K. E. Harms, "Seed arrival, ecological filters, and plant species richness: a meta-analysis," Ecology Letters, vol. 12, no. 11, pp. 1250-1260, 2009.

[8] T. Igarashi and Y. Kiyono, "The potential of hinoki (Chamaecyparis obtusa [Sieb. et Zucc.] Endlicher) plantation forests for the restoration of the original plant community in Japan," Forest Ecology and Management, vol. 255, no. 1, pp. 183-192, 2008.

[9] S. B. Jeffries, T. R. Wentworth, and H. L. Allen, "Longterm effects of establishment practices on plant communities across successive rotations in a loblolly pine (Pinus taeda) plantation," Forest Ecology and Management, vol. 260, no. 9, pp. 1548-1556, 2010. 
[10] D. B. Lindenmayer and R. J. Hobbs, "Fauna conservation in Australian plantation forests-a review," Biological Conservation, vol. 119, no. 2, pp. 151-168, 2004.

[11] T. Nagaike, A. Hayashi, and M. Kubo, "Is it necessary to change the number of samples for different forest types when evaluating plant species richness? A case study in a forested landscape in central Japan," Journal of Forest Research, vol. 15, no. 3, pp. 169-175, 2010.

[12] V. M. Proença, H. M. Pereira, J. Guilherme, and L. Vicente, "Plant and bird diversity in natural forests and in native and exotic plantations in NW Portugal," Acta Oecologica, vol. 36, no. 2, pp. 219-226, 2010.

[13] E. Weiher, A. van der Werf, K. Thompson, M. Roderick, E. Garnier, and O. Eriksson, "Challenging theophrastus: a common core list of plant traits for functional ecology," Journal of Vegetation Science, vol. 10, no. 5, pp. 609-620, 1999.

[14] H. Poorbabaei and G. Poorrahmati, "Plant species diversity in loblolly pine (Pinus teada L.) and sugi (Cryptomeria japonica D. Don) plantations in the Western Guilan, Iran," International Journal of Biodiversity and Conservation, vol. 1, pp. 38-44, 2009.

[15] L. L. Bremer and K. A. Farley, "Does plantation forestry restore biodiversity or create green deserts? A synthesis of the effects of land-use transitions on plant species richness," Biodiversity and Conservation, vol. 19, no. 14, pp. 3893-3915, 2010.

[16] A. Felton, E. Knight, J. Wood, C. Zammit, and D. Lindenmayer, "A meta-analysis of fauna and flora species richness and abundance in plantations and pasture lands," Biological Conservation, vol. 143, no. 3, pp. 545-554, 2010.

[17] J. Bauhus, P. ven der Meer, and M. Kanninen, Ecosystem Goods and Services from Plantation Forests, Earthscan, 2010.

[18] M. J. Broncano, M. Vilà, and M. Boada, "Evidence of Pseudotsuga menziesii naturalization in montane Mediterranean forests," Forest Ecology and Management, vol. 211, no. 3, pp. 257-263, 2005.

[19] F. Essl, D. Moser, S. Dullinger, T. Mang, and P. E. Hulme, "Selection for commercial forestry determines global patterns of alien conifer invasions," Diversity and Distributions, vol. 16, no. 6, pp. 911-921, 2010.

[20] R. D. Nyland, Silviculture, McGrow Hill, 1996.

[21] S. Heinrichs and W. Schmidt, "Short-term effects of selection and clear cutting on the shrub and herb layer vegetation during the conversion of even-aged Norway spruce stands into mixed stands," Forest Ecology and Management, vol. 258, no. 5, pp. 667-678, 2009.

[22] Y. Kubota, K. Katsuda, and K. Kikuzawa, "Secondary succession and effects of clear-logging on diversity in the subtropical forests on Okinawa Island, southern Japan," Biodiversity and Conservation, vol. 14, no. 4, pp. 879-901, 2005.

[23] K. Nagashima, S. Yoshida, and T. Hosaka, "Patterns and factors in early-stage vegetation recovery at abandoned plantation clearcut sites in Oita, Japan: possible indicators for evaluating vegetation status," Journal of Forest Research, vol. 14, no. 3, pp. 135-146, 2009.

[24] T. Nagaike, T. Yoshida, H. Miguchi, T. Nakashizuka, and T. Kamitani, "Rehabilitation for species enrichment in abandoned coppice forests in Japan," in Restoration of Boreal and Temperate Forests, J. A. Stanturf and P. Madsen, Eds., pp. 371381, CRC Press, Boca Raton, Fla, USA, 2005b.

[25] K. Sakuta, S. Taniguchi, A. Inoue, and N. Mizoue, "Effects of strip-cutting on stand floor micro climate and tree-species diversity in a Japanese cypress plantation," Journal of the Japanese Forestry Society, vol. 91, no. 2, pp. 86-93, 2009 (Japanese).
[26] S. Ito, S. Ishigami, N. Mizoue, and G. P. Buckley, "Maintaining plant species composition and diversity of understory vegetation under strip-clearcutting forestry in conifer plantations in Kyushu, southern Japan," Forest Ecology and Management, vol. 231, no. 1-3, pp. 234-241, 2006.

[27] H. Yamagawa, S. Ito, K. Sakuta, N. Mizoue, and T. Nakao, "Effects of small-scale clearcutting management on species diversity and vertical structure of understory vegetation of a conifer plantation comprising uneven-aged stands, in Kyushu, Southern Japan," Journal of the Japanese Forestry Society, vol. 91, no. 4, pp. 277-284, 2009.

[28] S. Miura, S. Yoshinaga, and T. Yamada, "Protective effect of floor cover against soil erosion on steep slopes forested with Chamaecyparis obtusa (hinoki) and other species," Journal of Forest Research, vol. 8, no. 1, pp. 27-35, 2003.

[29] H. Kon, I. Watanabe, and M. Yasaka, "Effect of thinning on the natural regeneration of broad-leaved trees in Abies sachalinensis plantations," Journal of the Japanese Forestry Society, vol. 89, no. 6, pp. 395-400, 2007 (Japanese).

[30] N. Hanada, M. Shibuya, H. Saito, and K. Takahashi, "Regeneration process of broadleaved trees in planted Larix kaempferi forests," Journal of the Japanese Forestry Society, vol. 88, no. 1, pp. 1-7, 2006 (Japanese).

[31] H. T. Ishii, M. A. Maleque, and S. Taniguchi, "Line thinning promotes stand growth and understory diversity in Japanese cedar (Cryptomeria japonica D. Don) plantations," Journal of Forest Research, vol. 13, no. 1, pp. 73-78, 2008.

[32] A. Hirata, T. Sakai, K. Takahashi et al., "Effects of management, environment and landscape conditions on establishment of hardwood seedlings and saplings in central Japanese coniferous plantations," Forest Ecology and Management, vol. 262, no. 7, pp. 1280-1288, 2011.

[33] M. Nagai and T. Yoshida, "Variation in understory structure and plant species diversity influenced by silvicultural treatments among 21- to 26-year-old Picea glehnii plantations," Journal of Forest Research, vol. 11, no. 1, pp. 1-10, 2006.

[34] Y. Son, Y. Y. Lee, Y. C. Jun, and Z.-S. Kim, "Light availability and understory vegetation four years after thinning in a Larix leptolepis plantation of central Korea," Journal of Forest Research, vol. 9, no. 2, pp. 133-139, 2004.

[35] A. Cooper, T. McCann, and D. Ridge, "Vegetation development in second rotation Irish conifer plantations," Forest Ecology and Management, vol. 255, no. 3-4, pp. 962-972, 2008.

[36] T. Hino and T. Hiura, "Effects of disturbance history and environmental factors on the diversity and productivity of understory vegetation in a cool-temperate forest in Japan," Forest Ecology and Management, vol. 257, no. 3, pp. 843-857, 2009.

[37] T. Masaki, S. Mori, T. Kajimoto et al., "Long-term growth analyses of Japanese cedar trees in a plantation: neighborhood competition and persistence of initial growth deviations," Journal of Forest Research, vol. 11, no. 4, pp. 217-225, 2006.

[38] T. Nishizono, K. Tanaka, K. Hosoda, Y. Awaya, and Y. Oishi, "Effects of thinning and site productivity on culmination of stand growth: results from long-term monitoring experiments in Japanese cedar (Cryptomeria japonica D. Don) forests in northeastern Japan," Journal of Forest Research, vol. 13, no. 5, pp. 264-274, 2008.

[39] G. Kerr, "The use of silvicultural systems to enhance the biological diversity of plantation forests in Britain," Forestry, vol. 72, no. 3, pp. 191-205, 1999.

[40] R. T. Busing and S. L. Garman, "Promoting old-growth characteristics and long-term wood production in Douglas-fir 
forests," Forest Ecology and Management, vol. 160, no. 1-3, pp. 161-175, 2002.

[41] W. Suzuki, T. Suzaki, T. Okumura, and S. Ikeda, "Aginginduced development patterns of Chamaecyparis obtusa plantations," Journal of the Japanese Forestry Society, vol. 87, no. 1, pp. 27-35, 2005 (Japanese).

[42] R. Ferris, A. J. Peace, J. W. Humphrey, and A. C. Broome, "Relationships between vegetation, site type and stand structure in coniferous plantations in Britain," Forest Ecology and Management, vol. 136, no. 1-3, pp. 35-51, 2000.

[43] S. Ito, M. Nakagawa, G. P. Buckley, and K. Nogami, "Species richness in sugi (Cryptomeria japonica D. DON) plantations in southeastern Kyushu, Japan: the effects of stand type and age on understory trees and shrubs," Journal of Forest Research, vol. 8, no. 1, pp. 49-57, 2003.

[44] M. R. Roberts, "Effects of forest plantation management on herbaceous-layer composition and diversity," Canadian Journal of Botany, vol. 80, no. 4, pp. 378-389, 2002.

[45] B. V. Ramovs and M. R. Roberts, "Response of plant functional groups within plantations and naturally regenerated forests in southern New Brunswick, Canada," Canadian Journal of Forest Research, vol. 35, no. 6, pp. 1261-1276, 2005.

[46] T. Nagaike, "Snag abundance and species composition in a managed forest landscape in central japan composed of Larix kaempferi plantations and secondary broadleaf forests," Silva Fennica, vol. 43, no. 5, pp. 755-766, 2009.

[47] R. Ferris and J. W. Humphrey, "A review of potential biodiversity indicators for application in British forests," Forestry, vol. 72, no. 4, pp. 313-328, 1999.

[48] T. Nagaike, A. Hayashi, and M. Kubo, "Diversity of naturally regenerating tree species in the overstorey layer of Larix kaempferi plantations and abandoned broadleaf coppice stands in central Japan," Forestry, vol. 83, no. 3, pp. 285-291, 2010.

[49] T. Nagaike, A. Hayashi, M. Abe, and N. Arai, "Differences in plant species diversity in Larix kaempferi plantations of different ages in central Japan," Forest Ecology and Management, vol. 183, no. 1-3, pp. 177-193, 2003.

[50] T. Nagaike, A. Hayashi, M. Kubo, M. Abe, and N. Arai, "Plant species diversity in a managed forest landscape composed of Larix kaempferi plantations and abandoned coppice forests in Central Japan," Forest Science, vol. 52, no. 3, pp. 324-332, 2006.

[51] K. Takahashi and T. Kamitani, "Effect of dispersal capacity on forest plant migration at a landscape scale," Journal of Ecology, vol. 92, no. 5, pp. 778-785, 2004.

[52] Z. Dzwonko, "Effect of proximity to ancient deciduous woodland on restoration of the field layer vegetation in a pine plantation," Ecography, vol. 24, no. 2, pp. 198-204, 2001.

[53] M. Wulf and T. Heinken, "Colonization of recent coniferous versus deciduous forest stands by vascular plants at the local scale," Applied Vegetation Science, vol. 11, no. 3, pp. 307-316, 2008.

[54] R. S. Gonzales and T. Nakashizuka, "Broad-leaf species composition in Cryptomeria japonica plantations with respect to distance from natural forest," Forest Ecology and Management, vol. 259, no. 10, pp. 2133-2140, 2010.

[55] E. Utsugi, H. Kanno, N. Ueno et al., "Hardwood recruitment into conifer plantations in Japan: effects of thinning and distance from neighboring hardwood forests," Forest Ecology and Management, vol. 237, no. 1-3, pp. 15-28, 2006.
[56] K. Seiwa, M. Ando, A. Imaji, M. Tomita, and K. Kanou, "Spatio-temporal variation of environmental signals inducing seed germination in temperate conifer plantations and natural hardwood forests in northern Japan," Forest Ecology and Management, vol. 257, no. 1, pp. 361-369, 2009.

[57] A. Sakai, T. Sakai, S. Kuramoto, and S. Sato, "Soil seed banks in a mature Hinoki (Chamaecyparis obtusa Endl.) plantation and initial process of secondary succession after clearcutting in southwestern Japan," Journal of Forest Research, vol. 15, no. 5, pp. 316-327, 2010.

[58] H. Zhu, Z. F. Xu, H. Wang, and B. G. Li, "Tropical rain forest fragmentation and its ecological and species diversity changes in southern Yunnan," Biodiversity and Conservation, vol. 13, no. 7, pp. 1355-1372, 2004.

[59] A. Helm, I. Hanski, and M. Pärtel, "Slow response of plant species richness to habitat loss and fragmentation," Ecology Letters, vol. 9, no. 1, pp. 72-77, 2006.

[60] M. Vellend, K. Verheyen, H. Jacquemyn et al., "Extinction debt of forest plants persists for more than a century following habitat fragmentation," Ecology, vol. 87, no. 3, pp. 542-548, 2006.

[61] S. Iida and T. Nakashizuka, "Forest fragmentation and its effect on species diversity in sub-urban coppice forests in Japan," Forest Ecology and Management, vol. 73, no. 1-3, pp. 197-210, 1995.

[62] K. Fukamachi, S. Iida, and T. Nakashizuka, "Landscape patterns and plant species diversity of forest reserves in the Kanto region, Japan," Vegetatio, vol. 124, no. 1, pp. 107-114, 1996.

[63] H. Ishida, T. Hattori, and Y. Takeda, "Comparison of species composition and richness among primeval, natural, and secondary lucidophyllous forests on Tsushima Island, Japan," Vegetation Science, vol. 22, pp. 1-14, 2005a (Japanese).

[64] H. Ishida, T. Hattori, Y. Hashimoto et al., "Comparison of species composition and richness among primeval, natural, and secondary lucidophyllous forests in southeastern Kyushu, Japan," Vegetation Science, vol. 22, pp. 71-86, 2005b (Japanese).

[65] S. Fujii, Y. Kubota, and T. Enoki, "Long-term ecological impacts of clear-fell logging on tree species diversity in a subtropical forest, southern Japan," Journal of Forest Research, vol. 15, no. 5, pp. 289-298, 2010.

[66] H. Ishida, T. Hattori, Y. Takeda, and S. Kodate, "Relationship between species richness or species composition and area of fragmented lucidophyllous forests in southeastern Hyogo Prefecture," Japanese Journal of Ecology, vol. 48, no. 1, pp. 116, 1998 (Japanese).

[67] H. Tamura and K. Shimano, "Various plants habitats of shrines in the Matsumoto basin, Nagano, central Japan," Landscape Ecology and Management, vol. 14, pp. 53-66, 2009 (Japanese).

[68] K. Murakami, F. Uwakubo, N. Izumoto, and Y. Morimoto, "An adaptation of the focal species approach for conserving the woody plant species diversity in fragmented shrine forests in urban or suburban landscapes," Landscape Ecology and Management, vol. 14, pp. 41-51, 2009 (Japanese).

[69] K. Takeuchi, R. D. Brown, I. Washitani, A. Tsunekawa, and M. Yokohari, Satoyama: The Traditional Rural Landscape of Japan, Springer, Tokyo, Japan, 2003.

[70] T. Matsumura, T. Hattori, Y. Hashimoto, and K. Ban, "Relationship between cover of evergreen species and species richness or species composition of coppice forest in Hokusetsu 
area, Hyogo, western Japan," Vegetation Science, vol. 24, pp. 41-52, 2007 (Japanese).

[71] T. Nakashizuka, "Regeneration of beech (Fagus crenata) after the simultaneous death of undergrowing dwarf bamboo (Sasa kurilensis)," Ecological Research, vol. 3, no. 1, pp. 21-35, 1988.

[72] H. Tomimatsu, H. Yamagishi, I. Tanaka, M. Sato, R. Kondo, and Y. Konno, "Consequences of forest fragmentation in an understory plant community: extensive range expansion of native dwarf bamboo," Plant Species Biology, vol. 26, no. 1, pp. 3-12, 2011.

[73] K. Shimada, T. Katsuki, K. Iwamoto, and O. Saito, "Managemnt effects on the community structure and species richness of secondary Quercus serrate-Q. acutissima woodland in the southwest Tama area, Tokyo, Japan," Vegetation Science, vol. 25, pp. 1-12, 2008 (Japanese).

[74] S. Nakagawa, "Approaches to Satoyama conservation," in Satoyama: The Traditional Rural Landscape of Japan, K. Takauchi et al., Ed., Springer, Tokyo, Japan, 2003.

[75] A. Felton, M. Lindbladh, J. Brunet, and Ö. Fritz, "Replacing coniferous monocultures with mixed-species production stands: an assessment of the potential benefits for forest biodiversity in northern Europe," Forest Ecology and Management, vol. 260, no. 6, pp. 939-947, 2010.

[76] M. Scherer-Lorenzen, C. Körner, and E. D. Schulze, Forest Diversity and Function, Springer, 2005.

[77] C. Healy, N. J. Gotelli, and C. Potvin, "Partitioning the effects of biodiversity and environmental heterogeneity for productivity and mortality in a tropical tree plantation," Journal of Ecology, vol. 96, no. 5, pp. 903-913, 2008.

[78] R. Jobidon, G. Cyr, and N. Thiffault, "Plant species diversity and composition along an experimental gradient of northern hardwood abundance in Picea mariana plantations," Forest Ecology and Management, vol. 198, no. 1-3, pp. 209-221, 2004.

[79] W. Koerner, J. L. Dupouey, E. Dambrine, and M. Benoît, "Influence of past land use on the vegetation and soils of present day forest in the Vosges mountains, France," Journal of Ecology, vol. 85, no. 3, pp. 351-358, 1997.

[80] H. Taki, T. Inoue, H. Tanaka et al., "Responses of community structure, diversity, and abundance of understory plants and insect assemblages to thinning in plantations," Forest Ecology and Management, vol. 259, no. 3, pp. 607-613, 2010. 

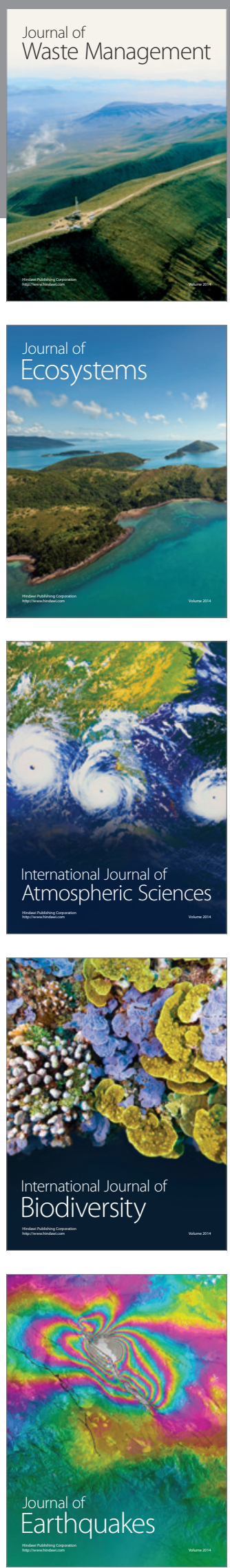
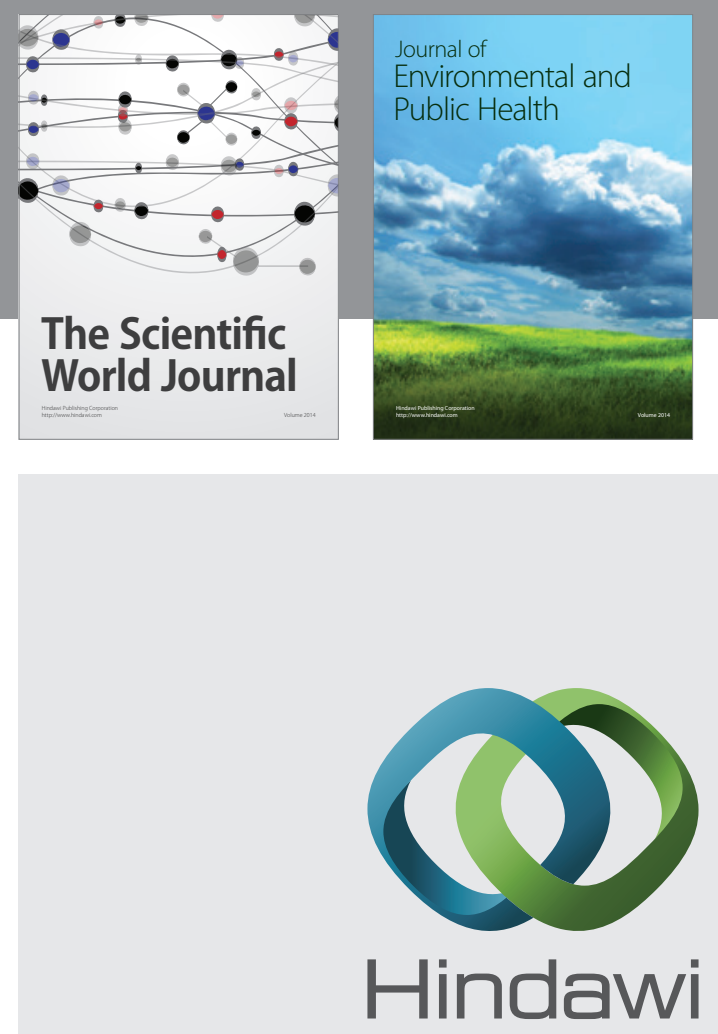

Submit your manuscripts at

http://www.hindawi.com
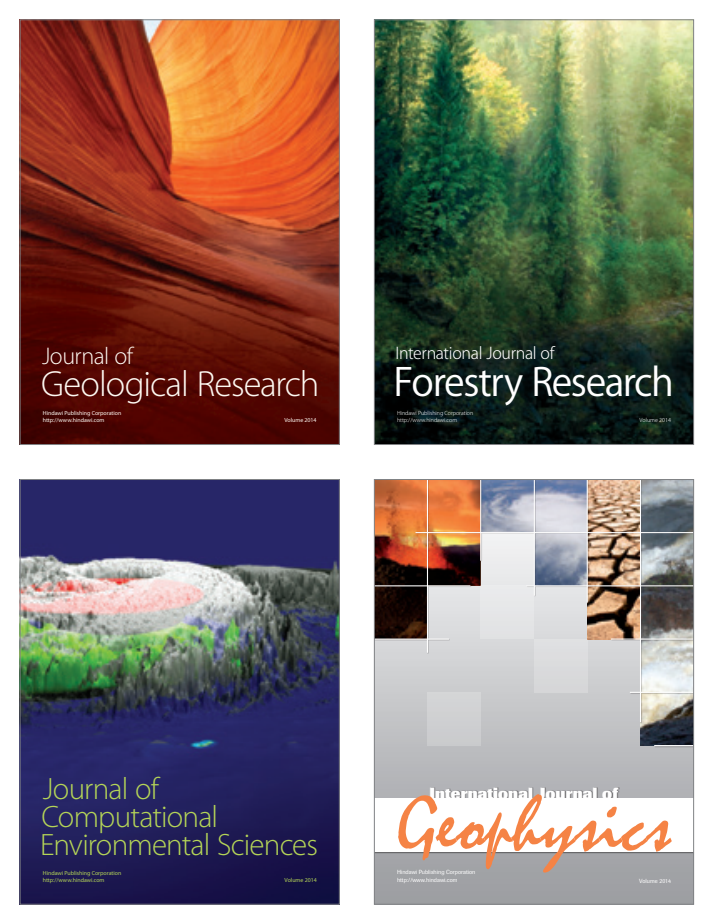
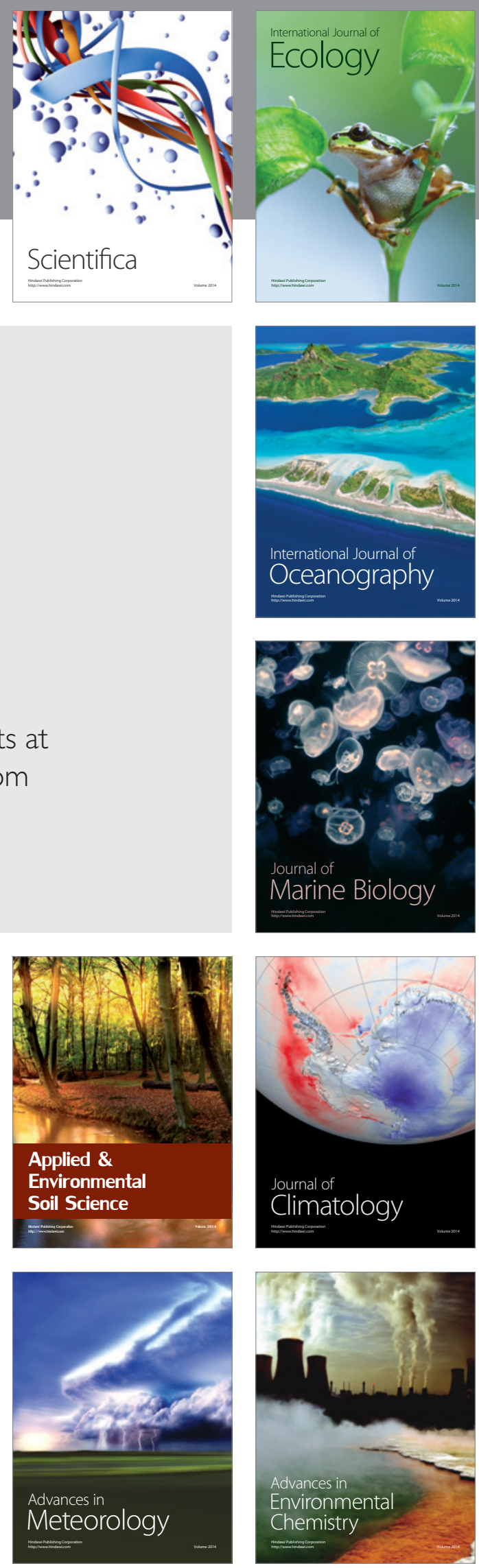